\title{
Pemanfaatan Ms.Excel untuk Pembukuan Keuangan UMKM Desa Bangsal Kecamatan Pampangan
}

\author{
Sugandi Yahdin ${ }^{1}$, Anita Desiani* ${ }^{*}$, Desty Rodiah ${ }^{3}$, Dwi Puspa Indriani ${ }^{4}$, Irmeilyana ${ }^{5}$ \\ 1,2,4,5Fakultas MIPA Universitas Sriwijaya \\ ${ }^{3}$ Fakultas Ilmu Komputer, Universitas Sriwijaya \\ *e-mail: Anita_desiani@unsri.ac..id ${ }^{2}$
}

\begin{abstract}
Bangsal Village is in the Pampangan OKI of South Sumatera. Bangsal Village has community groups of micro small and medium enterprises (UMKM) including Buffalo Cattle, Palm Sugar and Buffalo Milk Jelly Producers. So far, the bookkeeping and financial reports carried out by the UMKM group are still manual paper records. In addition, UMKM don't have staff to manage their financial reports, but by involving Ibnul Falah high school students. The students don't have enough knowledge to use the computer technology like Ms.Excel for financial reports. The ms.excel workshop activities are given to community and ward village students in order to manage financial reports and bookkeepings easily. In addition, assistance and evaluation are also carried out so that the material is truly understood. The results are quite good, it can be seen from the average score obtained from the assignment, which is 76.7 and the average written test score is 78.1 .
\end{abstract}

Keywords: Bangsal, Excel, bookeepings, finance UMKM

\begin{abstract}
Abstrak
Desa Bangsal berada di kecamatan Pampangan OKI Sumatera Selatan. Desa Bangsal memiliki kelompok masyarakat usaha mikro kecil dan menenngah (UMKM) diantaranya Ternak Kerbau, Produsen Gula Puan dan Produsen Jelly Susu Kerbau. Selama ini pembukuan dan laporan keuangan yang dilakukan oleh kelompok UMKM tersebut masih manual catatan kertas dan buku. Selain itu UMKM belum memiliki tenaga khusus untuk mengelola pembukuan dan laporan keuangan mereka, tetapi dengan melibatkan siswa SMA Ibnul Falah yang ada di desa Bangsal. Siswa SMA Ibnul Falah belum mengetahui pemanfaatan teknologi komputer salah satunya MS.Excel untuk mengelola pembukuan dan laporan keuangangan. Pemanfaatan Ms.Excel diberikan kepada masyarakat dan para siswa SMA yang menjadi admin pembukuan pada UMKM dalam bentuk materi, pelatihan dan pendampingan. Hasil dari kegiatancukup baik terlihat dari rata-rata nilai yang diperoleh dari tugas yaitu 76,7 dan rata-rata nilai tes tertulis sebesar 78,1.
\end{abstract}

Kata kunci: Bangsal, Excel, Keuangan, Pembukuan, UMKM

\section{PENDAHULUAN}

Sumatera Selatan sebagai provinsi terluas peringkat ke 6 di Indonesia, dan provinsi terluas di pulau sumatera memiliki 4 kota dan 13 kabupaten dengan kecamatan sebanyak 236 dan 2.853 desa yang tersebar dengan berbagai karakteristik dan sumber daya alam yang berbedabeda. Salah satu kabupaten yang ada di Sumatera Selatan adalah Ogan Komering Ilir (OKI). Kabupaten Oki memiliki daerah rawa yang paling luas dibandingkan kabupaten lain. $75 \%$ wilayah kabupaten OKI adalah wilayah rawa(BPS-Statistics of Sumatera Selatan, 2016). Kecamatan Pampangan merupakan salah satu kecamatan pada kabupaten OKI yang memiliki 22 desa, salah satunya adalah Desa Bangsal yang berjarak sekitar $11 \mathrm{~km}$ dari pusat kota kecamatan yang dapat ditempuh sekitar 2,5 jam lewat jalur darat. Luas areal pemukiman Desa bangsal sebesar 5 Ha atau hanya sebesar 1,11\% dari total seluruh luas wilayah yang memiliki satu dusun, 2 RW dan 5 RT. Desa Bangsal memiliki lahan rawa gambut seluas 375 Ha dan digunakan sebagai lahan untuk perternakan kerbau dan lahan pertanian seperti sawah. Lahan yang telah dikelola sebagai perkebunan karet seluas 68,5 Ha. Dari data statistik tahun 2018 di kecamatan Pampangan tahun 2018, desa Bangsal memiliki 578 jiwa penduduk yang terdiri dari 278 pria dan 300 wanita dengan kepadatan sebesar 109 jiwa $/ \mathrm{km}^{2}$ (Wijaya, 2019). Desa Bangsal secara geografis termasuk bukan daerah pesisir tetapi berdasarkan topografi desa Bangsal merupakan daerah kawasan rawa dan 
aliran sungai yang berada di luar wilayah hutan. Perbatasan sekitar desa Bangsal dapat dilihat pada tabel 1 .

Tabel. 1. Perbatasan Desa Bangsal

\begin{tabular}{c|c}
\hline Batas & Desa / Kelurahan \\
\hline Selatan & Kuro \\
Utara & Ulak Depati \\
Barat & Tapus \\
Timur & Pulau Betung \\
\hline
\end{tabular}

Sebagian besar penduduk desa Bangsal berprofesi sebagai petani dan nelayan. Pertanian yang ada di desa Bangsal Meliputi persawahan, kebun, hortikultura dan pertanian apung. Untuk perikanan desa Bangsal adalah ikan rawa seperti putak, gabus dan sebagainya. Desa Bangsal juga terkenal sebagai desa peternak kerbau rawa. Wilayah desa Bangsal merupakan dataran rendah yang masih menggunakan budaya ternak dan perikanan yang dilakukan secara konvensional. Pengolahan hasil desa berciri khas rawa dengan skala lokal. Desa bangsal memiliki satu sekolah dasar, satu sekolah menengah pertama (SMP) dan satu sekolah menengah tingkat atas (SMA) di bawah naungan yayasan Ibnul Falah. Yayasan Ibnul Fallaah (YASIFA) yang berarti anak petani, merupakan sebuah lembaga sosial masyarakat yang dibentuk secara swadaya oleh masyarakat Desa Bangsal dan memiliki fokus kerja pada bidang pendidikan, sosial, budaya, dan pengembangan ekonomi pedesaan berbasis keberlanjutan sumber daya alam setempat(Desiani et al., 2020).

Desa bangsal dulunya adalah desa terpencil yang tidak memiliki akses jalan darat untuk menuju ke desa lain atau ke ibukota kecamatan. Transportasi utama saat itu adalah perahu atau biasa yang disebut dengan Ketek. Namun sekarang desa Bangsal telah memiliki jalur darat sehigga memudahkan lalulintas penduduk desa untuk ke desa ataupun ke ibukota kecamatan. Berdasarkan hasil pemantauan dan diskusi dengan perangkat Desa Bangsal serta informasi dari masyarakat, desa Bangsal yang memiliki kelompok usaha kecil menengah (UMKM) peternak kerbau, kelompok produksi gula puan dan kelompok produksi jely susu dari susu kerbau. Proses manajemen pembukuan dan pencatatan laporan keuangan produksi dan pemasaran dari setiap produksi yang ada selama ini, dibantu oleh siswa siswi SMA yayasan dan koperasi Ibnul Falah desa Bangsal. Ibnul Falah awalnya merupak pesantren kecil di desa Bangsal yang berdiri tahun 2008. Posisi desa Bangsal yang dulu sulit untuk di akses melalui darat membuat pesantren tersebut berkembang terus dari yang awalnya hanya pesantren dan sekolah dasar sekarang makin berkembang dengan berdirinya SMP dan SMA di bawah yayasan Ibnul Falah. Keberadaan lembaga pendidikan yang didirikan oleh Ibnul Falah mampu membantu masyarakat desa dalam perkembangan informasi dan teknologi di desa Bangsal. SMA Ibnul Falah sendiri telah memiliki laboratorium komputer yang dilengkapi sebanyak 20 komputer sehingga siswa SMA Ibnu Falah di desa tersebut tidak hanya belajar untuk bekal mereka namun juga membantu masyarakat desa salah satunya adalah dalam memanajemen pembukuan dan pencatatan keuangan produk-produk yang ditawarkan oleh desa Bangsal. Sayangnya pembukuan dan pencatatan keuangan yang dilakukan masih dilakukan secara manual yaitu dengan menggunakan buku dan kertas tidak memanfaatkan teknologi komputer padahal fasilitas yang dimiliki oleh sekolah tersebut cukup lengkap dengan ketersedian komputer yang telah ada, sehingga diperlukan suatu pengenalan dan pelatihan teknologi yang dapat membantu pembukuan dan penyusunan laporan keuangan yang lebih teratur dan akurat dengan memanfaatkan teknologi informasi dan komputer (TIK).

Menurut Soemarso(Soemarsono, 1986) Laporan keuangan merupakan suatu wadah komunikasi yang umum digunakan oleh perusahaan atau badan-badan usaha, dimana di dalamnya memuat informasi keuangan yang bakal menjadi bahan masukkan dan pertimbangan dalam pengambilan berbagai keputusan dari berbagai permasalahan suatu perusahaan. Laporan keuangan dapat memberi dampak pada pemasukkkan suatu perusahaan untuk bisa mengetahui 
besar pemasukkan dan pengeluaran, yang dimanfaatkan sebagai informasi masukkan bagi pihak yang memerlukannya(Herawati, 2019; Rahmayuni, 2017). Pembukuan dan pencatatat laporan keuangan yang baik sangat diperlukan oleh UMKM untuk membantu perkembangan kemajuan suatu UMKM (Floren Violetfin et al., 2013; Hapsari et al., 2017). Ikatan Akuntansi Indonesia telah menerbitkan Standar Akuntansi Keuangan untuk Entitas Tanpa Akuntabilitas Publik (SAK ETAP) yang berlaku efektif 1 Januari 2011 dengan tujuan untuk mengimplementasikan berbagai hal yang berkaitan dalam keuangan pada entitas tanpa memerlukan akuntabilitas publik salah satunya yaitu UMKM(Floren Violetfin et al., 2013; Ikatan Akuntansi Indonesia, 2009). Penerbitan ini diharapkan agar UMKM yang ada di Indonesia dapat memiliki laporan keuangan sebagai media untuk menganalisis kinerja keuangan sehingga dapat menghasilkan informasi tentang posisi keuangan, kinerja, dan arus kas dalam usahanya. Namun pada umumnya, pemilik UMKM hanya berfokus pada pencarian keuntungan dari hasil usahanya tanpa ingin dibuat susah dengan keharusan membuat laporan keuangan, untuk itu tim pengabdian FMIPA UNSRI melakukan pelatihan ini pada setiap usaha yang dilakukan oleh masyarakat Desa Bangsal sehingga dapat membuat dan menggunakan pembukuan dan laporan keuangan secara sederhana berbasik TIK.

Salah satu solusi yang diusulkan adalah yang terkait dengan penataan keuangan, melalui pelatihan penyusunan pembukuan dan penyusunan laporan keuangan sederhana dengan menggunakan perangkat lunak yang berbasis TIK yaitu microsoft excel (MS. Excel). Laporan keuangan yang berdasarkan prinsip akuntansi biasanya disajikan dalam format laporan atau statement, sementara teknologi informasi lebih memberi peluang untuk dapat menyajikan informasi dalam berbagai format dan bentuk, baik secara teks, grafik, sound, tabulasi dan sebagainya(Taufiq, 2017). Penyajian informasi dengan excel dapat dilakukan dengan lebih mudah dan menarik. Microsoft Excel adalah aplikasi yang dapat digunakan untuk mengolah data harian dengan skala kecil maupun besar, yang mudah dipahami dan di pelajari serta menghasilkan laporan keuangan yang relatif singkat dengan kebutuhan pemilik sehingga pemilik mengerti keadaan financial perusahaan yang sebenarnya(Triandi \& Stephanie, 2010; Zahara et al., 2013).

Berbagai kegiatan pelatihan pemanfaat Excel untuk masyarakat desa telah banyak dilakukan tidak hanya untuk pengelolaan pembukuan dan keuangan tetapi juga untuk yang lain seperti pengelolaan administrasi desa pada pada beberapa wilayah diantaranya di kecamatan Jumantono kabupaten Karanganyar (Wibowo, 2017), di kecamatan Panekan Kabupaten Magetan (Andari \& Lusiana, 2016) dan pelatihan adminstrasi desa di Desa Ciaruteun Ilir Kecamatan Cibungbulang, Kabupaten Bogor (Ajie et al., 2019). Pelatihan excel untuk membantu berbagai elemen masyarakat desa juga telah banyak dilakukan diantaranya pelatihan keuangan dengan menggunakan MS Excel untuk para UMKM di desa Galang Suka, kecamatan Galang, kabupaten Deli Sumatera Utara (Riza \& Ariani, 2019). Pelatihan Keuangan juga pernah diberikan untuk Lembaga Perkreditan Desa (LPD) di Desa Adat Kuum Keladi Tabanan Bali (Nurcahya et al., 2017), dan Badan Usaha Milik Desa di Desa Bandung Kecamatan Diwek Jombang (Hidayah et al., 2018). Kondisi masyarakat desa Bangsal saat ini cukup memiliki pendidikan yang memadai sehingga memiliki kualitas dan kemampuan yang layak untuk dapat dilatih dalam mengelola dan mengatur hal-hal yang berkaitan dengan teknologi saat ini. Kekurangan mereka dalam mengelola keuangan dan pembukuan atau pencataan produksi-produksi yang ada pada UMKM desa Bangsal dapat diatasi dengan memberikan mereka pelatihan dan pendampingan agar mereka dapat menguasai dan memahami bagaimana mengelola data pembukuan dan keuang mereka dengan memamfaatkan teknologi saat ini salah satunya yaitu MS. Excel.

\section{METODE PELAKSANAAN}

2.1 Metode Ceramah, merupakan metode yang diberikan oleh tim FMIPA Unsri melalui tatap muka dimana tim memaparkan teori-teori yang berkaitan dengan dengan akuntansi yang meliputi pembukuan, manajemen keuangan, dan pelaporan keuangan, serta materi TIK yang meiputi Microsoft office dan titik beratnya adalah untuk aplikasi Microsoft excel. Teori-teori tersebut dijelasan secara detail dan dengan bahasa komunikasi yang mudah agar para 
peserta pelatihan mampu memahami materi dengan baik dan menguasai untuk nantinya dipraktekan pada sesi praktikum.

2.2 Diskusi dan Tanya jawab, metode ini akan dilakukan setelah materi yang diberikan kepada peserta selanjutnya untuk melihat sejauh mana pemahaman dari peserta terhadap materi maka akan dilakukan diskusi dan Tanya jawab.

2.3 Praktikum, peserta pelatihan akan diberikan modul-modul pelatihan dan kasus-kasus yang terkait dengan pelaporan keuangan, kemudian memberikan tugas secara mandiri sehingga peserta mempraktekkan langsung aplikasi microsof excel untuk menyelesaikan kasus-kasus yang diberikan. Praktikum ini juga akan melihat bagaimana para peesrta mengimplementasi teori yang telah dipelajari ke dalam aplikasi Ms. Excel, selain itu peserta juga mampu membandingkan efektifitas dan efisiensi pembuatan laporan keuangan yang dilakukan secara manual dan dilakukan secara komputerisasi.

2.4 Evaluasi, yaitu memberikan ujian kepada para peserta untuk mengukur tingkat pemahaman penguasaan materi-materi yang diberikan dengan menyebarkan kuisioner yang harus diisi peserta. Penilaian kuisioner menggunakan nilai rata-rata dimana kuisioner tersebut sebelumnya diuji validatas pers(1) dan reabilitas pers(2) menggunakan uji validitas dan reliabilitas dengan persamaan sebagai berikut (Ayunita \& Nurmala, 2018):

$$
r_{x y}=\frac{n\left(\sum X Y\right)-\left(\sum X\right)\left(\sum Y\right)}{\sqrt{\left[n\left(\sum X^{2}\right)-\left(\sum X\right)^{2} \mid n\left(\sum Y^{2}\right)-\left(\sum Y\right)^{2}\right]}}
$$

Dimana, $r_{x y}=$ koefisien korelasi suatu butir/item; $\mathrm{N}=$ jumlah subyek

$$
\mathrm{X}=\text { skor suatu butir/item; } \mathrm{Y}=\text { skor total }
$$

$r_{11}=\left[\frac{k}{k-1}\right]\left[1-\frac{\sum \sigma_{b}^{2}}{V_{t}^{2}}\right]$

Dimana, $r_{11}=$ reliabilitas instrument; $\mathrm{k}=$ banyaknya butir pertanyaan

$\sum \sigma_{b}^{2}=$ Jumlah Varian pertanyaan

$V_{t}^{2} \quad=$ varian total

\section{HASIL DAN PEMBAHASAN}

Desa Bangsal adalah desa yang produktif dengan berbagai hasil desa. Desa ini letaknya terpencil dibandingkan desa disekitarnya. Penduduk yang relatif sedikit sehingga masyarakat saling memberdayakan satu dengan yang lain dalam mengembangkan berbagai potensi desa. Beberapa kelompokUMKM telah berdiri di desa bangsal diantaranya adalah UMKM kelompok ternak kerbau rawa, kelompok usaha gula puan dan kelompok usaha jelly susu kerbau. Sayangnya untuk pembukuan dan laporan keuangan para kelompok UMKM ini masih melibatkan siswa-siswa SMA yang ada di desa Bangsal yaitu SMA Ibnul Falah.

Berdasarkan pengamatan yang dilakukan langsung di desa bangsal. Siswa-siswa SMA tersebut belum mengusai teknologi informasi dan komunikasi secara baik. Mereka melakukan pembukuan dan keuangan masih dengan cara konvensional hanya menggunakan catatan buku dan kertas. Padahal SMA ibnul Falah desa Bangsal telah memiliki fasilitas laboratorium komputer yang cukup memadai namun penggunaannya belum maksimal. Hasil wawancara dan survey yang kami lakukan sebelumnya, banyak di antara mereka yang sama sekali belum pernah menggunakan excel, sehingga harus dilatih dan didampingi sejak awal. Adapun pelatihan yang diberikan diantaranya adalah mengenal fungsi-fungsi matematika yang ada di excel seperti sum, count, max. min, menyusun bentuk tabel laporan dan lain-lain. Pembukuan dan pengelolaan laporan keuangan yang dilakukan secara konvensional memerlukan ketelitian dan keakuratan serta keamanan sehingga laporan tidak mudah rusak dan hilang. Pembukuan dan laporan keuangan dengan menggunakan microsoft excel dapat dibuat lebih rapi dan teliti. Microsoft excel (Ms. Excel) mampu menangani kesalahan dengan cepat dan akurat. Selain itu pembukuan dan 
laporan keuangan dengan Ms.excel lebih aman, rapi cepat dan akurat. Ms excel juga memiliki kelebihan bisa digunakan pada data dengan jumlah yang besar dan menggambarkan informasi dari data secara grafis. Kelebihan yang dimiliki oleh aplikasi Ms. Excel memberikan kemudahan dalam membuat laporan keuangan yang sesuai dan biasa digunakan di Indonesia.

Pelatihan Ms excel bagi kelompok-kelompok masyarakat UMKM di desa Bangsal diberikan kepada sekitar 15-20 orang siswa kelas 3 SMA Ibnul Fallah desa Bangsal. Pelatihan tersebut awalnya akan diperuntukan khusus kepada kelompok masyarakat UMKM didesa Bagsal. Tapi kendala yang terjadi adalah ternyata kelompok-kelompok UMKM di desa Bangsal melibatkan siswa SMA (terutama kelas 3) Ibnul Fallah untuk membantu pendataan,pembukuan dan laporan keuangan. Alasan tersebut sehingga diputusan bahwa untuk pelatihan Ms. Excel diberikan kepada para siswa SMA desa Bangsal. Keuntungan pelatihan ini diberikan kepada para siswa SMA adalah dari sisi pemahaman materi akan lebih cepat dan kesadaran untuk beradaptasi dengan teknologi baru akan lebih tinggi, hal ini dapat dilihat dari antusiasnya mereka mengikuti pelatihan ini. Selain itu siswa SMA ini akan menggunakan pengetahuan ini tidak saja saat pelatihan namun akan mereka gunakan sampai pada jenjang perkuliahan mereka nanti dan tentunya mereka akan selalui update dan beradaptasi dengan teknologi baru, hal ini sangat menguntungan bagi desa Bangsal. Untuk tahapan pelatihan yang dilakukan ada dua cara yaitu:

1. Pelatihan pertama dilakukan dengan metode ceramah dan pendampingan pelatihan dasardasar perintah untuk laporan keuangan dan pembukuan pada microsoft excel. Pelatihan ini dilakukan untuk memberikan pemahaman kepada peserta tentang Ms. Excel dan implementasinya pada bagian keuangan.

2. Pelatihan kedua memberikan tugas-tugas mandiri kepada peserta pelatihan, yang kemudian hasil akhir dari tugas tersebut akan menjadi penilaian sejauh mana peserta latih mampu memahami dan menguasai materi yang telah diberikan. Penilaian ini akan digunakan sebagai parameter dalam mengambil kesimpulan apakah para peserta benar-benar dapat menguasai materi, dan apakah perlu diberi tambahan untuk pemantapan agar penguasaan dan pemahaman mereka tentang Ms. Excel benar-benar seperti yang diharapkan yaitu mampu membuat laporan keuangan sesuai dengan standarnya.

Pengenalan aplikasi Ms. Excel untuk laporan keuangan dilakukan sebanyak dua kali. Pada pelatihan minggu pertama para peserta diberikan materi-materi dasar pengenalan Ms. Excel yang meliputi fitur-fitur dasar, menyusun tabel, dan menggunakan perintah-perintah dasar dalam Ms. Excel. Selain pemberian materi, peserta juga langsung mempraktekkan materi yang diberikan dengan didampingi oleh para tutor agar para peserta dapat lebih paham serta mengetahui penggunaan berbagai fitur dan perintah yang ada di dalam Ms.excel (Gambar 1). Salah satu kegiatan pelatihan minggu pertama dapat dilihat pada gambar 2 .

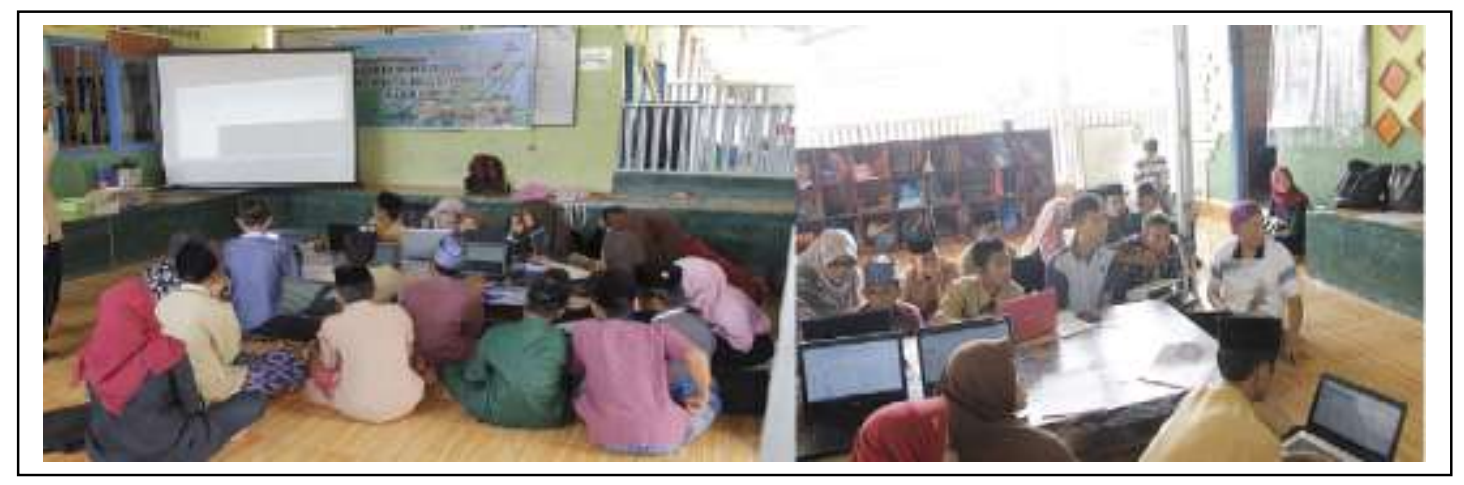

Gambar 1. Kegiatan Pelatihan yang Diberikan

Pada pelatihan minggu kedua para peserta diberikan tugas mandiri yang harus dapat diselesaikan dan disusun dalm bentuk laporan pembukuan keuangan yang sederhan. Rata-rata skor nilai Tugas yang diberikan adalah 76,7. Nilai tersebut menunjukkan peserta sudah cukup mampu memfaatkan MS.excel untuk laporn pembukuan keuangan. Pada 
pertemuan terakhir peserta diberikan kuisioner yang berisikan 10 pertanyaan yang ebrkaitan dengan materi yang telah diberikan. Sebelum kuisioner disebarkan, terlebih dahulu dilakukan uji kuisioner dari 10 pertaanyaan tersebut dengan mengambil sampel 8 orang dari total 23 peserta yang hadir. Hasil dari uji validitas dan reabilitas menunjukkan Koefisien Korelasi $r_{x y}=0,69$ yang artinya kuisioner tersebut cukup valid untuk digunakan. Untuk uji reabiliotas diperoleh koefisien reabilitas adalah sebesar $r_{t t}=0,71$, yang artinya kuisioner cukup handal untuk digunakan mengukur kemampuan peserta pelatihan dalam memahami materi yang diberikan. Rata-rata total nilai dari semua nilai peserta adalah 78,1 artinya secara umum pemahaman peserta cukup baik terhadap materi yang diberikan. Salah satu bentuk laporan yang berhasil disusun oleh salah satu peserta dapat dilihat pada gambar 3 .

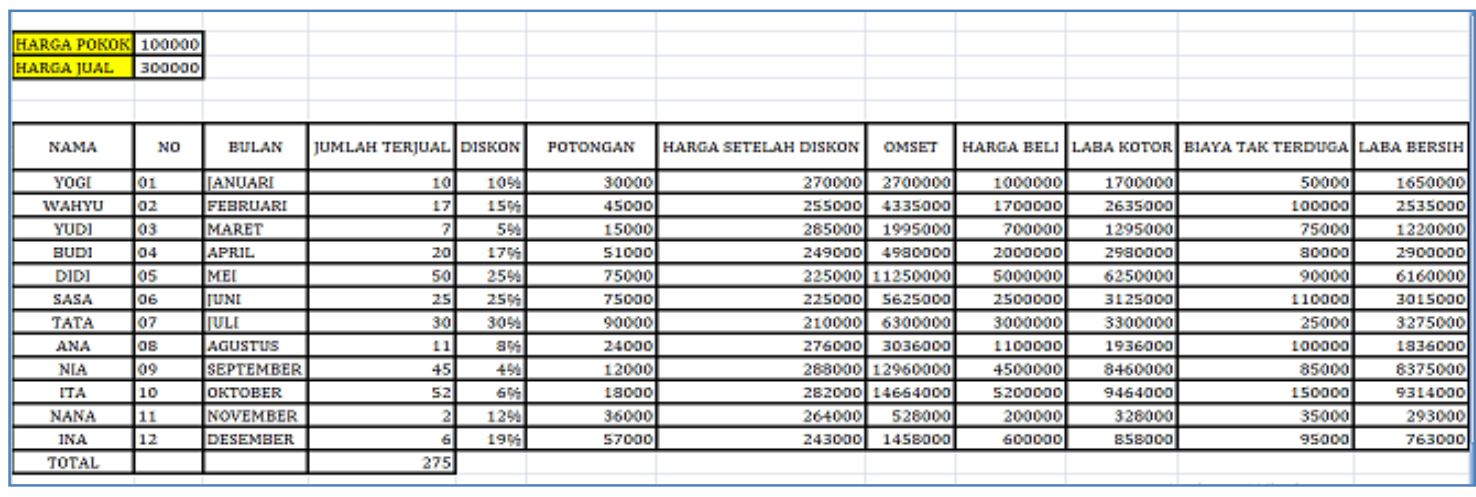

Gambar 2. Contoh Laporan Tugas Mandiri Salah Satu Peserta Pelatihan

Total rata-rata tugas mandiri dan nilai dari kuisioner adalah di atas 75 dapat dikatakan penguasaan materi dan penggunaan Ms.Excel sudah cukup baik oleh para peserta, namun masih perlu dikembangkan dengan kegiatan pendampingan yang berkelanjutan. Untuk pengelolaan data pembukuan dan laporan keuangan yang sederhana para peserta sudah dapat menggunakan Ms. Excel dengan cukup baik. Untuk laporan keuangan yang lebih lengkap dan mengacu pada standar yang ditetapkan oleh Sak Etap, peserta masih memerlukan pendampingan lebih lanjut sehingga UMKM di desa Bangsal benar-benar bisa memiliki laporan keuangan yang baik, akurat, cepat dan tersaji dengan baik.

\section{KESIMPULAN}

Dari kegiatan pendampingan dan pelatihan yang diberikan mengenai pembukuan dan laporan keuangan, dapat disimpulkan bahwa kegiatan ini sangat bermanfaat bagi masyarakat desa Bangsal terutama kelompok UMKM. Hasil kegiatan pelatihan yang diberikan menunjukkan bahwa peserta cukup mampu menguasai materi yang diberikan dan mampu menerapkannya dalam mengelola pembukuan dan laporan keuangan. Pada pelatihan ini materi yang diberikan masih berfokus pada fitur-fitur yang dimiliki oleh Ms. Excel dan laporan keuangan yang sederhana, belum banyak berfokus pada standar laporan keuangan yang diakui secara umum dan nasional. Dari kekurangan tersebut kegiatan ini dapat dilanjutkan dengan materi yang lebih berfokus pada bagaimna menyusun pembukuan dan laporan keuangan yang lebih kompleks dan lengkap.

\section{DAFTAR PUSTAKA}

Ajie, M. T., Yosrita, E., Rusjdi, D., Indah, N. M., Indrianto, I., Cahyaningtyas, R., Arianti, D., \& Bedi, H. (2019). Pelatihan MS. Office Word dan Excel Bagi Perangkat Desa dan Masyarakat Desa Ciaruteun Ilir Bogor. Terang, 1(1), 86-95. https://doi.org/10.33322/terang.v1i1.209

Andari, T., \& Lusiana, R. (2016). Pemberdayaan desa melalui pelatihan pengoperasian. JURNAL 
TERAPAN ABDIMAS, 1(1), 29-31.

Ayunita, D., \& Nurmala, N. (2018). Modul Uji Validitas dan Reliabilitas (Issue October).

BPS-Statistics of Sumatera Selatan. (2016). Sumatera Selatan Province in Figure 2016. https://doi.org/11012001.16

Desiani, A., Yahdin, S., Irmeilyana, I., \& Rodiah, D. (2020). Inovasi digitalisasi promosi potensi dan produk usaha masyarakat desa berbasis website di Desa Bangsal Kecamatan Pampangan. Riau Journal of Empowerment, 3(1), 49-59. https://doi.org/10.31258/raje.3.1.49-59

Floren Violetfin, L., Fefri Indra, A., \& Citra, R. (2013). Penerapan Standar Akutansi Keuangan Entitas Tanpa Akuntasi Publik (Studi Kasus Pada CV. Citra Pandion Bernas di Kabupaten Solok). ECONOMICA, 1(2).

Hapsari, D. P., Andari, \& Ade, N. H. (2017). Model Pembukuan Sederhana Bagi Usaha Mikro di Kecamatan Kramatwatu Kabupaten Serang. Jurnal Akutansi, 4(2), 36-47.

Herawati, H. (2019). Pentingnya Laporan Keuangan untuk Menilai Kinerja Keuangan Perusahaan. Jurnal Akuntansi Unihaz - JAZ, 2(1), 16-25.

Hidayah, A. T., Pujiati, L., Hidyati, N., Hendrawan, S. A., Suprapto, S., \& Ali, N. (2018). Pendampingan Penyusunan Laporan Keuangan Pada Badan Usaha Milik Desa (Bumdes) Lestari Desa Bandung Kecamatan Diwek Jombang. Comvice : Journal of Community Service, 2(1), 15-20. https://doi.org/10.26533/comvice.v2i1.123

Ikatan Akuntansi Indonesia. (2009). Standar Akutansi Keuangan; Entitas Tanpa Akuntabilitas Publik.

Nurcahya, I. N., Sulistyawati, E., \& Wira. (2017). Pelatihan Penyusunan Laporan Keuangan Berbasis Excel LPD Desa Adat Kuum Keladi Tabanan. Buletin Udayana Mengabdi, 16(3), 307315.

Rahmayuni, S. (2017). Peranan Laporan Keuangan Dalam Menunjang Peningkatan Pendapatan Pada Ukm. JURNAL Sosial, Humaniora Dan Pendidikan, 1(1).

Riza, F. V., \& Ariani, R. (2019). Pelatihan Manajemen Keuangan Berbasis Excel pada Unit Up2k di Desa Galang Suka. Seminar Nasional Kewirausahaan, 1(1), 373-377.

Soemarsono, S. (1986). Akuntansi: Suatu Pengantar (2nd ed.). LP FEUI.

Taufiq, M. (2017). Pengaruh Teknologi Informasi Dalam Keprofesian dan Implikasinya Dalam Dunia Pendidikan. Naturalistic, 1(2), 176-185.

Triandi, \& Stephanie, T. (2010). Penerapan Proses Akuntansi Menggunakan Microsoft Excel Dalam Penyusunan Laporan Keuangan Pada Perusahaan Sinar Harapan. Jurnal Ilmiah Ranggagading, 10(2), 113-120.

Wibowo, E. (2017). Pelatihan Microsoft Excel dan Power Point Bagi Perangkat Desa Sebagai Upaya Peningkatan Administrasi Desa yang Berkualitas Di Kecamatan Jumantono Kabupaten Karananyar. ADIWIDYA, 1(1). https://doi.org/10.1017/CB09781107415324.004

Wijaya, T. (2019). Lanskap Lestari, Cara Desa Bangsal Berdaulat Pangan dan Menjaga Bentang Alam. Mongabay. Lanskap Lestari, Cara Desa Bangsal Berdaulat Pangan dan Menjaga Bentang Alam

Zahara, Sukartini, Amy, F., Eliyanora, \& Yossi, S. (2013). Perancangan Model Penyusunan Laporan Keuangan Perusahaan dengan Program Excell For Accounting(EFA). Simposium Nasional Akuntansi Vokasi Ke-2, 17-18. 